\title{
POHON INDUSTRI (INTERAKTIF) SEBAGAI PENGEMBANGAN LAYANAN INFORMASI DI PERPUSTAKAAN PDDI LIPI
}

\author{
Mohamad Djaenudin \\ Pusat Data dan Dokumentasi Ilmiah - Lembaga Ilmu Pengetahuan Indonesia \\ Email:djaenudin2002@yahoo.com \\ Tupan \\ Pusat Data dan Dokumentasi Ilmiah - Lembaga Ilmu Pengetahuan Indonesia \\ Email: tupan71290@gmail.com
}

Received : 18 July 2021 Revised : 26 September 2021 Accepted : 09 October 2021 DOI

\begin{abstract}
(Objectives) The purpose of writing this paper is to explain the process of making industrial trees (interactive) as an information service development activity carried out by the Center for Scientific Data and Documentation (PDDI) which is useful for the community because it provides an overview and stimulates entrepreneurs to carry out and develop product diversification with economic value through the schematic presented. (Method) The stages of making an industrial tree start from topic selection, literature search, article selection and analysis, then proceed with visualization which is then posted on the web.. (Findings) The result of this research showed that audit experience, audit expertise, and locus of control significantly positive affect audit judgment taken by the auditor.
\end{abstract}

Keywords: Information services, Industrial tree (interactive), PDDI LIPI.

\section{PENDAHULUAN}

Sejak berdiri PDDI LIPI selalu berkomitmen sebagai pusat atau sumber pengetahuan dan katalisator dalam mempercepat diseminasi ilmu pengetahuan sehingga civitas di dalamnya harus selalu kreatif dan inovatif dalam menyediakan layanan dan membantu dalam mengembangkan keterampilan dan kepercayaan diri kepada masyarakat. Hal ini sejalan dengan tugas dan fungsi Pusat Data dan Dokumentasi Ilmiah (PDDI) LIPI yaitu menyediakan, mengolah dan menyebarluaskan informasi yang bersifat ilmiah atau ilmu pengetahuan dan teknologi kepada masyarakat. Terutama terkait dengan hasil penelitian dan pengolahan karya ilmiah yang dikemas ulang agar dapat dipahami dan dimanfaatkan oleh masyarakat luas sesuai kebutuhan (Pebrianti, 2015)

Salah satu kegiatan yang telah dilakukan oleh PDDI adalah menyediakan berbagai jenis kemasan informasi yang dijadikan sebagai produk pengetahuan seperti pohon industri yang merupakan upaya dalam menyediakan kemasan pengetahuan yang sesuai dengan pengguna di masyarakat. Pohon industri yaitu paket kemasan informasi berisi ulasan, skema, dan pemanfaatannya serta referensi (sumber artikel) yang terkait dengan topik 
tertentu. Kemasan informasi ini disusun berdasarkan fungsi dan manfaat suatu komoditas yang bernilai ekonomis dengan memberikan deskripsi jenis-jenis produk yang dapat dibuat dari suatu komoditas untuk merangsang pengusaha melakukan dan mengembangkan diversifikasi produk yang bernilai ekonomi (Tupan dan Nashihuddin (2015).

Sebenarnya produk pengetahuan pohon industri adalah salah satu bentuk layanan informasi yang dilakukan oleh pusat dokumentasi dan informasi seperti PDDI LIPI sejak tahun 1999, waktu itu sedang masa-masa krisis moneter. PDDI LIPI membuat kemasan ulang informasi sebagai bisnis informasi berupa pohon industri, dan panduan usaha. PDDI juga ikut serta dalam membantu masyarakat yang terkena imbas dari krisis moneter dengan mengadakan pelatihan untuk meningkatkan keterampilan sehingga membuka usaha baru yang dapat kembangkan dari hasil pelatihan.

Produk pengetahuan tersebut pada waktu itu sangat membantu masyarakat terutama bagi yang ingin berwiraswasta membangun usaha baru setelah terkena PHK, dengan memanfaatkan informasi baik produk pohon industri maupun panduan usaha. Namun seiring dengan kemajuan teknologi informasi yang berkembang dengan cepat, di mana semua terbitan tercetak sudah tidak lagi mendominasi, maka produk pengetahuan seperti pohon industri pun akhirnya dibuat dengan menggunakan teknologi informasi dengan nama pohon industri interaktif, yang dapat dipasang di Website lembaga sehingga dapat diakses oleh masyarakat melalui Internet secara luas (Rahma, 2020 ).

Untuk mengoptimalkan pemanfataan pohon industri interaktif ini belakangan PDDI LIPI melakukan kerjasama dengan Pemerintah Daerah agar dapat menjangkau pemanfaatan ke daerah-daerah yang memiliki komoditi sumber daya tanaman yang cukup potensial untuk dikembangkan. Sebagai contoh pada tahun 2019 PDDI bekerjasama dengan Pemda Banyuwangi dimana potensi tanaman bahan pangan terbesarnya adalah produksi tanaman padi, yang menjadi lumbung padi di Provinsi Jawa Timur. Produksi komoditas unggul lainnya adalah jeruk, cabai, buah naga, pisang, dan durian.

Oleh karena itu agar komoditas unggul tersebut dapat dimanfaatkan oleh masyarakat luas, maka PDDI LIPI melakukan kemas ulang komoditas daerah (bahan pangan dan perkebunan) menjadi pohon industri interaktif dengan memanfaatkan sumber informasi atau database yang dimiliki seperti Indonesian Scientific Journal Database (ISJD), Repositori Ilmiah Nasional (RIN), dan lain-lain serta dengan mengoptimalkan teknologi informasi dan komunikasi.

Di sisi lain, seperti yang kita ketahui bersama, bahwa tidak semua karya ilmiah dan hasil kegiatan ilmiah lainnya dapat dimanfaatkan langsung oleh masyarakat dikarenakan 
ketidaktahuan masyarakat dalam mengakses dan memilah informasi yang begitu cepat pertumbuhannya. Selain itu, di PDDI sendiri belum maksimal dalam memanfaatkan dan menyebarkan produk pengetahuannya. Agar pohon industri yang telah dibuat dapat dimanfaatkan oleh banyak masyarakat perlu divisualisasikan dan diinformasikan melalui media peta digital. Dengan melakukan pemetaan ini, harapannya produk pengetahuan akan lebih mudah dibaca dan dimanfaatkan oleh masyarakat.

Khusus untuk PDDI LIPI karena saat ini tugasnya bertambah untuk mengelola data, maka Visualisasi Data merupakan salah satu bentuk kemasan infromasi yang penting, terlebih-lebih saat ini dunia berada di era Big Data. Visualisasi data adalah bentuk lain dari seni visual. Seseorang yang melihat grafik, akan dengan cepat melihat tren dan outlier, dan dengan demikian akan lebih mudah menginternalisasikan data secara cepat. Saat ini tersedia banyak alat untuk melakukan visualisasi data dimulai dari yang sederhana sampai yang rumit (Tableu, 2020).

Untuk menjawab permaslahan tersebut diatas, Perpustakaan PDDI LIPI mengembangan layanan dengan pembuatan pohon industri interaktif. Pengembangan layanan dengan pohon industri interaktif bertujuan untuk memberikan gambaran kepada masyarakat, bahwa pohon industri (interaktif) ternyata dapat merangsang pengusaha melakukan dan mengembangkan diversifikasi produk yang bernilai ekonomi melalui skema yang disajikan. Sejak berdiri PDDI LIPI selalu berkomitmen sebagai pusat atau sumber pengetahuan dan katalisator dalam mempercepat diseminasi ilmu pengetahuan sehingga civitas di dalamnya harus selalu kreatif dan inovatif dalam menyediakan layanan dan membantu dalam mengembangkan keterampilan dan kepercayaan diri kepada masyarakat. Hal ini sejalan dengan tugas dan fungsi Pusat Data dan Dokumentasi Ilmiah (PDDI) LIPI yaitu menyediakan, mengolah dan menyebarluaskan informasi yang bersifat ilmiah atau ilmu pengetahuan dan teknologi kepada masyarakat. Terutama terkait dengan hasil penelitian dan pengolahan karya ilmiah yang dikemas ulang agar dapat dipahami dan dimanfaatkan oleh masyarakat luas sesuai kebutuhan (Pebrianti, 2015)

Salah satu kegiatan yang telah dilakukan oleh PDDI adalah menyediakan berbagai jenis kemasan informasi yang dijadikan sebagai produk pengetahuan seperti pohon industri yang merupakan upaya dalam menyediakan kemasan pengetahuan yang sesuai dengan pengguna di masyarakat. Pohon industri merupakan produk kemasan informasi mencakup ulasan, skema, dan pemanfaatannya serta referensi (sumber artikel) yang terkait dengan topik tertentu (Djaenudin dan Trianggoro, 2019). Kemasan informasi ini disusun berdasarkan fungsi dan manfaat suatu komoditas yang bernilai ekonomis dengan 
memberikan deskripsi jenis-jenis produk yang dapat dibuat dari suatu komoditas untuk merangsang pengusaha melakukan dan mengembangkan diversifikasi produk yang bernilai ekonomi (Tupan dan Nashihuddin (2015).

Sebenarnya produk pengetahuan pohon industri adalah salah satu bentuk layanan informasi yang dilakukan oleh pusat dokumentasi dan informasi seperti PDDI LIPI sejak tahun 1999, waktu itu sedang masa-masa krisis moneter. PDDI LIPI membuat kemasan ulang informasi sebagai bisnis informasi berupa pohon industri, dan panduan usaha. PDDI juga ikut serta dalam membantu masyarakat yang terkena imbas dari krisis moneter dengan mengadakan pelatihan untuk meningkatkan keterampilan sehingga membuka usaha baru yang dapat kembangkan dari hasil pelatihan.

Produk pengetahuan tersebut pada waktu itu sangat membantu masyarakat terutama bagi yang ingin berwiraswasta membangun usaha baru setelah terkena PHK, dengan memanfaatkan informasi baik produk pohon industri maupun panduan usaha. Namun seiring dengan kemajuan teknologi informasi yang berkembang dengan cepat, di mana semua terbitan tercetak sudah tidak lagi mendominasi, maka produk pengetahuan seperti pohon industri pun akhirnya dibuat dengan menggunakan teknologi informasi dengan nama pohon industri interaktif, yang dapat dipasang di Website lembaga sehingga dapat diakses oleh masyarakat melalui Internet secara luas (Rahma, 2020 ).

Untuk mengoptimalkan pemanfataan pohon industri interaktif ini belakangan PDDI LIPI melakukan kerjasama dengan Pemerintah Daerah agar dapat menjangkau pemanfaatan ke daerah-daerah yang memiliki komoditi sumber daya tanaman yang cukup potensial untuk dikembangkan. Sebagai contoh pada tahun 2019 PDDI bekerjasama dengan Pemda Banyuwangi dimana potensi tanaman bahan pangan terbesarnya adalah produksi tanaman padi, yang menjadi lumbung padi di Provinsi Jawa Timur. Produksi komoditas unggul lainnya adalah jeruk, cabai, buah naga, pisang, dan durian.

Oleh karena itu agar komoditas unggul tersebut dapat dimanfaatkan oleh masyarakat luas, maka PDDI LIPI melakukan kemas ulang komoditas daerah (bahan pangan dan perkebunan) menjadi pohon industri interaktif dengan memanfaatkan sumber informasi atau database yang dimiliki seperti Indonesian Scientific Journal Database (ISJD), Repositori Ilmiah Nasional (RIN), dan lain-lain serta dengan mengoptimalkan teknologi informasi dan komunikasi.

Di sisi lain, seperti yang kita ketahui bersama, bahwa tidak semua karya ilmiah dan hasil kegiatan ilmiah lainnya dapat dimanfaatkan langsung oleh masyarakat dikarenakan ketidaktahuan masyarakat dalam mengakses dan memilah informasi yang begitu cepat 
pertumbuhannya. Selain itu, di PDDI sendiri belum maksimal dalam memanfaatkan dan menyebarkan produk pengetahuannya. Agar pohon industri yang telah dibuat dapat dimanfaatkan oleh banyak masyarakat perlu divisualisasikan dan diinformasikan melalui media peta digital. an Adanya pemetaan ini, diharapkanan produk pohon industri lebih mudah diakses dan dimanfaatkan oleh masyarakat.

Khusus untuk PDDI LIPI karena saat ini tugasnya bertambah untuk mengelola data, maka Visualisasi Data merupakan salah satu bentuk kemasan infromasi yang penting, terlebih-lebih saat ini dunia berada di era Big Data. Visualisasi data adalah bentuk lain dari seni visual. Seseorang yang melihat grafik, akan dengan cepat melihat tren dan outlier, dan dengan demikian akan lebih mudah menginternalisasikan data secara cepat. Saat ini tersedia banyak alat untuk melakukan visualisasi data dimulai dari yang sederhana sampai yang rumit (Tableu, 2020).

Untuk menjawab permaslahan tersebut diatas, Perpustakaan PDDI LIPI mengembangan layanan dengan pembuatan pohon industri interaktif. Pengembangan layanan dengan pohon industri interaktif bertujuan untuk memberikan gambaran kepada masyarakat, bahwa pohon industri (interaktif) ternyata dapat merangsang pengusaha melakukan dan mengembangkan diversifikasi produk yang bernilai ekonomi melalui skema yang disajikan.

\section{METODE}

Metode pembuatan pohon industri ini dimulai dengan menentukan topik atau judul komoditi yang akan dibuat kemudian menentukan database atau sumber informasi untuk melakukan penelusuran informasi baik lokal maupun global. Setelah mengumpulkan hasil penelusuran kemudian dilakukan analisis dan dikelompokkan sesuai manfaat dari bagian dari komoditi tersebut dengan menuangkan langsung ke dalam tabel yang telah dibuat. Proses selanjutnya adalah desain dan visualisasi dengan menggunakan aplikasi komputer. Selengkapnya proses pembuatan pohon industri interaktif dapat dilihat pada Gambar 1. 


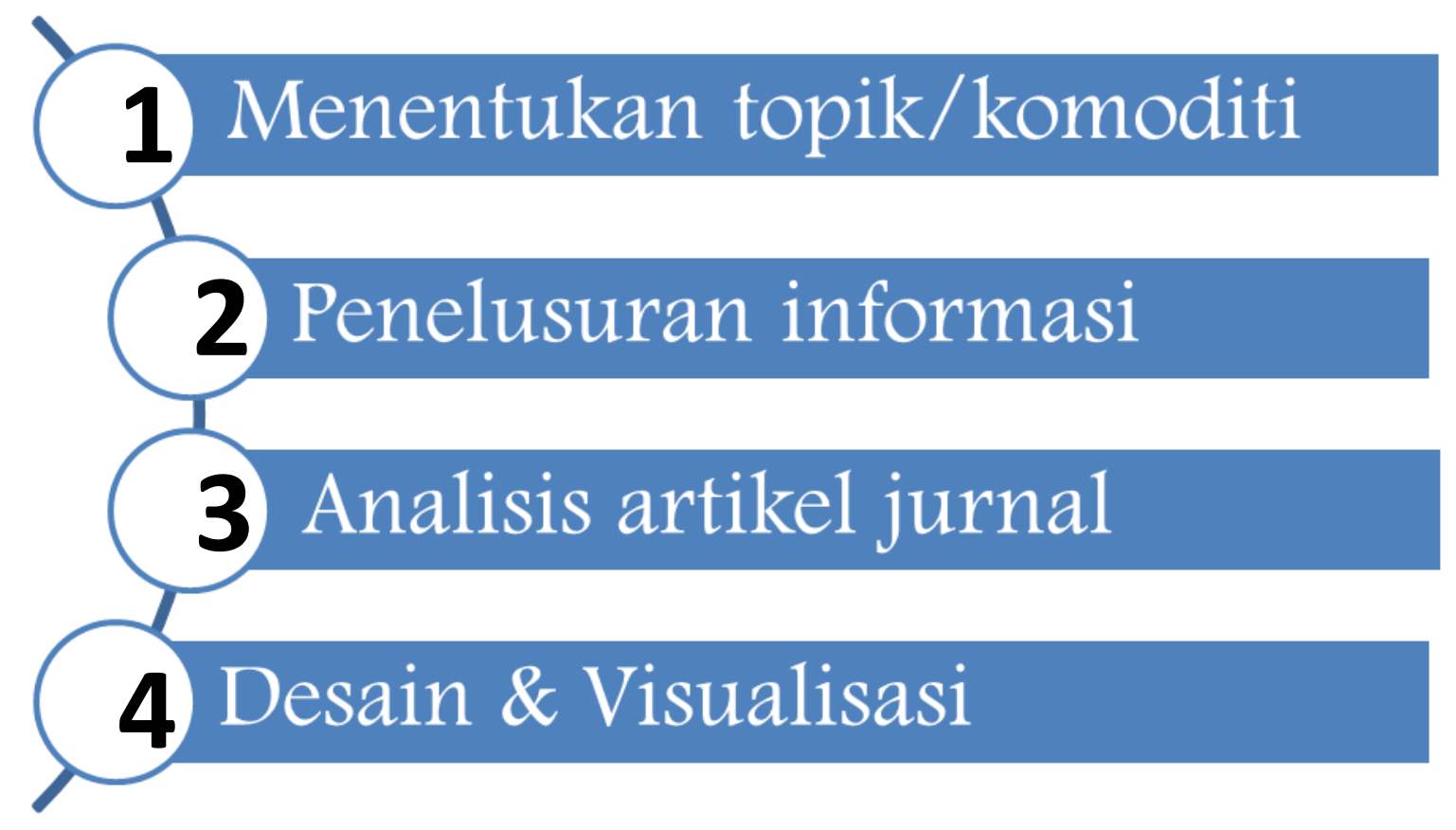

Gambar 1. Alur proses pembuatan pohon industri interaktif

\section{HASIL DAN PEMBAHASAN}

\section{Pengertian Pohon Industri}

Pohon industri merupakan produk kemasan informasi yang mencakup ulasan, skema, dan pemanfaatannya serta referensi (sumber artikel) yang terkait dengan topik tertentu. Pohon industri disusun menurut fungsi dan manfaat suatu komoditas yang mempunyai nilai ekonomis dengan tujuan memberikan gambaran tentang jenis-jenis produk yang dapat dimanfaatkan dari suatu komoditas, produk tersebut dapat memotivasi pengusaha melakukan inovasi diversifikasi produk yang bernilai ekonomi (Tupan dan Nashihuddin (2015).

Dalam dunia industri pohon industri merupakan diagram yang menggambarkan produk turunan dari suatu komoditas, atau komponen pembentuk suatu produk. Pohon industri yang dibuat diambil dari berbagai sumber untuk melihat gambaran umum tentang kemungkinan yang dapat dihasilkan dari pengolahan suatu komoditas. Pengertian di atas tidak jauh berbeda di kalangan pustakawan dari aspek kegiatan kemas ulang informasi setelah melakukan analisis terhadap berbagai artkel jurnal ilmiah. Djaenudin dan Trianggoro (2020) menyebutkan bahwa pohon industri merupakan kemas ulang informasi berisi ulasan, skema, dan pemanfaatannya serta referensi (sumber artikel) yang terkait dengan topik tertentu. Pohon industri disusun berdasarkan fungsi dan manfaat komoditas yang mempunyai nilai ekonomi dengan tujuan memberikan gambaran jenis-jenis produk yang dapat dimanfaatkan untuk merangsang pengusaha melakukan dan mengembangkan diversifikasi produk yang bernilai ekonomi . 
Agbaji \& Odumu (2017), menjelaskan bahwa langkah-langkah yang harus dilakukan dalam pohon industri interaktif adalah adalah:

a. Memiliki pengetahuan yang baik tentang target pengguna /pemustaka yang akan dilayani dan hal ini merupakan langkah yang sangat penting dalam proses pengemasan ulang informasi.

b. Memahami kebutuhan informasi dari kelompok sasaran.

Hal ini dapat dilakukan misalnya melalui wawancara lisan dengan orang-orang calon pengguna, pengamatan, interaksi dan lain lain.

c. Memilih format yang sesuai untuk mengemas ulang informasi

Pilihan format yang sesuai nantinya digunakan untuk mengemas ulang informasi tergantung pada kelompok sasaran. Apakah kelompok target melek huruf atau buta huruf? Adalah mereka penduduk kota atau desa? Apakah mereka anak muda, dan lain-lain.

d. Saluran penyebaran informasi

Ini adalah pilihan media untuk menyampaikan informasi kepada target kelompok. Jenis kelompok sasaran juga menentukan sebagian besar saluran informasi penyebaran. Sebagai contoh pesan kepada penduduk pedesaan dapat dilakukan melalui interaksi satu lawan satu, bercerita dan lain lain.

\section{Pembuatan pohon industri sebagai pengembangan layanan perpustakaan}

Agar dapat meningkatkan kinerja dan mengoptimalkan pemanfaatan sumberdaya informasi untuk melayani kebutuhan pemustaka, maka perpustakaan sebagai pusat informasi membutuhkan manajemen pengetahuan dalam pengelolaannya. Adanya layanan penelusuran informasi ilmiah baik langsung maupun online sejatinya umpan balik dari diseminasi informasi itu sendiri. Hal ini karena terjadi komunikasi dua arah tercipta secara berkesinambungan apabila jawaban terhadap permintaan penelusuran informasi tersebut telah disampaikan kepada pemustaka. Djaenudin dan Tupan (2020) menyebutkan pembuatan pohon industri adalah kegiatan mendayagunakan informasi yang telah dimiliki agar dapat bermanfaat bagi pemustaka sehingga terjadi diseminasi/penyebaran informasi yang yang tepat. Diseminasi informasi dilakukan, mengingat fungsi informasi dapat menjadi alat untuk mengambil kebijakan, menetapkan prioritas, dan dapat meningkatkan produktivitas dalam bekerja.

Sumberdaya informasi yang dimiliki perpustakaan dapat dijadikan bisnis informasi sebagai kegiatan untuk menambah nilai baik secara kredit poin maupun dana operasional perpustakaan. Melalui pengembangan sistem terpadu dengan membangun database online atau online jurnal yang dapat diakses oleh publik akan menjadi fakta bahwa hal tersebut memiliki nilai bisnis informasi sebagai komoditi pengetahuan yang dapat "dijual” kepada pemustaka atas dasar kepercayaan.

Melalui database yang dibangun maka situlah pustakawan dapat memanfaatkan sumber informasi dengan membuat kemas ulang informasi seperti pembuatan pohon industri. Proses pembuatan pohon industri tidak terlepas dari sumbedaya informasi yang tersedia di perpustakaan dan sumber informasi lainnya 
Untuk mempercepat proses diseminasi pengetahuan, tugas pusakawan sebagai katalisator mempunyai peran yang sangat penting di perpustakaan yang merupakan rumah sumber pengetahuan. Faktor menguatkannya literasi informasi masyarkat menjadi peran penting perpustakaan manakala dapat memfasilitasi masyarakat dalam mengembangkan potensinya melalui perpustakaan berbasis inklusi sosial. Melalui inovasi layanan perpustakaan dengan berbagai kegiatan seperti membuat kemasan informasi berupa pohon industri dapat mendukung terwujudnya perpustakaan berbasis inklusi sosial yang menekankan pada faktor manfaat perpustakaan yang dapat dirasakan di tengahtengah masyarakat.

Di era informasi ledakan informasi mendorong informasi yang diterima masyarakat di setiap sektor menjadi berlebihan. Adanya ledakan informasi, kemas ulang informasi dalam bentuk pohon industri merupakan salah satu solusi dalam memanfaatkan informasi karena dapat menghemat waktu, tenaga, dan biaya bagi pengguna. Kemas ulang informasi dalam bentuk pohon industri adalah proses sistematis untuk menambah nilai layanan informasi di perpustakaan. Ada tiga persyaratan untuk pengemasan ulang informasi; bahan harus dikumpulkandan terorganisir secara efisien, harus ada kapasitas untuk menganalisis konten mereka dan membuat paket informasi baru dari mereka, paket baru harus disebarluaskan secara bebas (Dongardive, 2013)

Di sinilah pustakawan menjadi garda terdepan dalam menggerakan pengetahuan untuk dapat dimanfaatkan secara aktif dan luas oleh masyarakat untuk mendukung transformasi pengetahuan menjadi tindakan aksi/inovasi yang memungkinkan adanya perubahan individu/ masyarakat ke arah yang lebih baik. Salah satunya dengan membuat kemasan informasi pohon industri interaktif sebagai kegiatan alternatif untuk merespon kebutuhan pemustaka dengan kemasan yang dianalisis secara terseleksi. Kemasan ini disajikan dalam bentuk semenarik mungkin dan interaktif sehingga pemustaka dapat memahami dengan mudah.

Pengembangan layanan informasi menjadi tantangan tersendiri bagi pustakwan agar lebih kreatif dalam melayani informasi sebab diperlukan kecermatan dan daya analisis yang akurat. Diperlukan kemampuan pustakawan yang mempunyai kompetensi personal yang kuat, karena di samping membutuhkan kerjasama tim yang solid juga kreatifitas yang tinggi.

Agar stakeholder dapat dilibatkan dalam pembuatan pohon industri ini maka pemilihan judul atau komoditi sebelumnya dibicarakan secara bersama melalui kerjasama sehingga dapat disesuaikan dengan komoditi potensi daerah yang menjadi unggulan. Mengapa demikian, karena jika tidak sesuai maka masyarakat di daerah tersebut kurang mendapat manfaat dari kemasan pohon industri yang dibuat. Pohon industri interaktif ini sedapat mungkin dapat dimanfaatkan secara optimal oleh masyarakat terutama dalam rangka mengembangkan produk turunan dari sebuah komoditi yang terdapat dalam kemasan pohon industri interaktif.

Kemudian di manakah kemasan pohon industri dapat diakses oleh masyarakat daerah? Jawabnya tentu ada di Internet/Website yang dimiliki oleh daerah/stakeholder yang sudah melakukan kerjasama. Biasanya melalui kerjasama telah disebutkan bahwa setelah pembuatan pohon 
industri interaktif selesai dibuat akan dipasang di website resmi lembaga. Pemasangan pohon industri interaktif ke dalam website lembaga akan memudahkan masyarakat luas untuk mengakses, dengan harapan dapat mengaplikasikan dalam kehidupan sehari-hari dan juga agar dapat memicu inovasi-inovasi yang dimiliki sehingga dapat mengembangkan SDM baik masyarakat lokal maupun nasional, serta mampu menciptakan masyarakat yang inklusif nan mandiri.

Menjadikan masyarakat yang inklusif nan mandiri adalah tujuan kita bersama dalam mendukung program pemerintah. Pustakawan dalam hal ini melalui pembuatan kemasan informasi pohon industri interaktif dapat dijadikan model contoh/pedoman/ide bagi pengembangan kreatifitas pustakawan dalam menyediakan layanan informasi yang selektif, inovatif serta efisien sesuai kebutuhan pemustaka, dan mendukung pengembangan perpustakaan berbasis inklusi sosial. Pengemasan ulang informasi dalam bentuk pohon industri adalah cara untuk meningkatkan layanan perpustakaan, khususnya di era informasi elektronik. Pustakawan harus memberikan pemikiran kritis fenomena ini dengan maksud untuk mengimplementasikannya dalam layanan perpustakaan rutin kepada pengguna (Dongardive, 2013).

\section{Proses pembuatan pohon industri (interaktif)}

Ada beberapa tahapan yang harus dilakukan dalam pembuatan pohon industri interaktif, yaitu menentukan judul atau komoditi yang akan dibuat, menelusur sumber informasi ke berbagai sumber lokal maupun global, menganalisis artikel dengan membuat tabel analisis, dan desain dan visualisasi.

Visualisasi data merupakan ringkasan informasi visual yang dapat memudahkan seseorang untuk mengidentifikasi pola dan tren daripada melihat melalui ribuan baris pada spreadsheet. Tujuan analisis data adalah untuk memperoleh wawasan, maka data jauh lebih berharga ketika divisualisasikan. Analis data dapat menarik wawasan dari data tanpa visualisasi, akan lebih sulit untuk mengkomunikasikan artinya tanpa visualisasi. Bagan dan grafik temuan data dapat dikomunikasikan dengan lebih mudah menggunakan visualisasi (Import.io., 2019).

\section{Menentukan topik/komoditi}

Langkah pertama yang pertama dilakukan adalah menentukan topik atau judul pohon industri yang akan dibuat. Pada awal pembuatan pohon industri, PDDI mengambil kebijakan yaitu komoditi sudah banyak dikenal atau sedang tren di masyarakat pada waktu tertentu atau tergantung permintaan dari pemustaka dari kalangan industri. Namun pada saat ini biasanya komoditi yang menjadi andalan suatu daerah tertentu yang akan menjadi obyek kerjasama dalam memanfaatkan produk pengetahuan pohon industri. Dalam hal ini 
dilakukan penandatangan kesepakatan kerjasama terlebih dahulu antara PDDI dengan Pemerintah Daerah/Lembaga (Tupan dan Nashihuddin (2015).

Apabila sudah disepakati maka langkah selajutnya adalah PDDI membentuk tim pembuatan pohon industri untuk melukakan tugas tersebut. Biasanya satu tim terdiri dari 2 orang pustakawan untuk satu judul /topik pohon industri yang bertugas menelurus informasi dan menganalisis artikel jurnal.

\section{Penelusuran informasi}

Selajutnya tim melakukan penelusuran informasi ilmiah terkait topik komoditi yang akan dibuat dengan menetapkan database atau sumber informasi yang akan dijadikan bahan rujukan, seperti ISJD, RIN, Portal Garuda, Google scholar, Springer, dan sebagainya. Kemudian menentukan kata kunci atau subyek dengan fokus pada manfaat dari daun, buah/bunga, batang, dan akar (jika tanaman) yang dihasilkan. Di samping menentukan sumber informasi yang akan dijadikan rujukan juga yang perlu diperhatikan adalah bentuk terbitan seperti artikel jurnal dan batasan tahun terbit dari suatu artikel, misalnya 20 tahun, 10 tahun, atau 5 tahun terakhir. Hal ini bertujuan agar informasi yang disajikan dapat semutahir mungkin. Contoh tahapan penelusuran literatur dapat dilihat dalam diagram gambar 2 berikut sebagai berikut.

\section{Database}

ISJD, RIN, Garba Rujukan Digital (GARUDA), Scopus, Google scholar, Springer, e-Resources. Sciencedirect

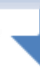

\section{Kata Kunci}

Panili/Vanila/vanilla, Vanilla planifolia (daun, bunga/buah, batang, akar)

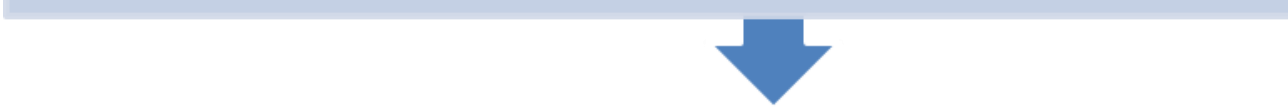

\section{Bentuk terbitan: Artikel jurnal}

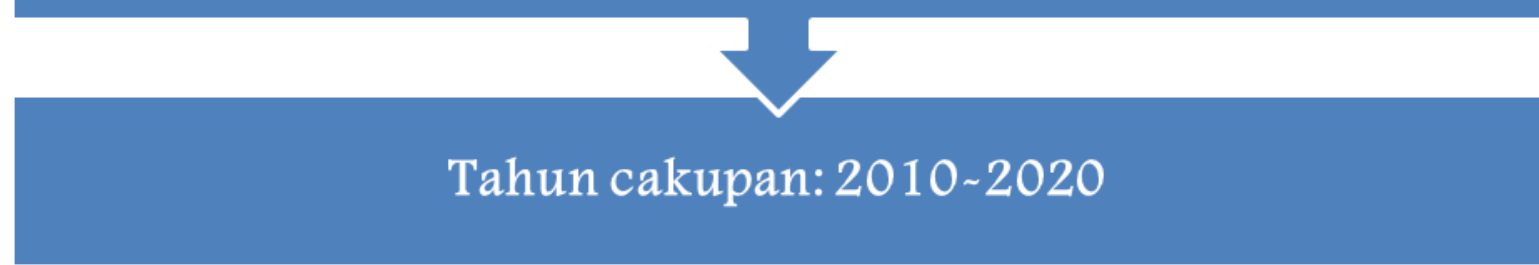

Gambar 2. Tahapan penelusuran Informasi 


\section{Melakukan analisis artikel jurnal}

Setelah memahami tahapan tersebut maka, langkah selajutnya adalah melakukan penelusuran informasi melalui database dengan menggunakan kata kunci yang sudah ditentukan. Hasil penelusuran dikumpulkan sebanyak mungkin agar saat melakukan analisis dapat menghasilkan temuan tentang manfaat komoditi yang akan dijadikan pohon industri.

Setelah artikel terkumpul dari hasil penelusuran, proses selanjutnya adalah melakukan analisis informasi. Analisis dilakukan dengan membaca secara teliti baik abstrak, pendahuluan, studi pustaka, pembahasan, maupun kesimpulan. Biasanya dengan membaca abstrak dan kesimpulan hasil analisis dapat ditemukan. Hasil analisis langsung dituangkan dalam tabel yang sudah dibuat. Berikut contoh tabel analisis pembuatan pohon industri panili dari hasil penelusuran artikel jurnal dapat dilihat pada Tabel 1 berikut:

Tabel 1. Analisis pohon industri panili

Tabel Analisis: Pohon Industri Panili

\begin{tabular}{|c|c|c|c|}
\hline Bagian Pohon & Proses & Hasil & Keterangan \\
\hline Daun & Ekstrak & $\begin{array}{l}\text { Antimikroba } \\
\text { Antijamur } \\
\text { Antikanker } \\
\text { Antinyamuk }\end{array}$ & \\
\hline Batang & Ekstrak & Antinyamuk & \\
\hline \multirow[t]{3}{*}{ Buah Panili } & Ekstrak & $\begin{array}{l}\text { Antidiabetes } \\
\text { 1. Penvedap makanan } \\
\text { 2. Penvedap rasa } \\
\text { makanan } \\
\text { Pengawet makanan } \\
\text { (antioksidan) } \\
\text { Suplemen kesehatan } \\
\text { Antimikroba } \\
\text { Antikanker } \\
\text { Antijamur } \\
\text { Vanilin } \\
\text { Kosmetik }\end{array}$ & \\
\hline & Spektrofootometri & Vanilin & \\
\hline & $\begin{array}{l}\text { Mikroenkapsulasi } \\
\text { Ekstrak }\end{array}$ & Bubuk vanili & \\
\hline Biji & Ekstrak & $\begin{array}{l}\text { Bahan pengawet } \\
\text { Minuman } \\
\text { Antikanker } \\
\text { Antijamur } \\
\text { Ice creams }\end{array}$ & \\
\hline Akar & Ekstrak & Anti nyamuk & \\
\hline
\end{tabular}

Tabel di atas dapat dijelaskan sebagai berikut: 
1. Daun panili bisa dijadikan bahan antimikroba, antijamur, antikanker, dan antinyamuk melalui proses ekstrak

2. Batang panili juga dapat digunakan sebagai antinyamuk dengan proses ekstrak.

3. Buah panili melalui proses ekstrak dapat menghasilkan obat antidiabet, penyedap makanan, pengawet makanan, suplemen kesehatan, antimikroba, antikanker, antijamur, dan bahan kosmetik. Dapat juga digunakan sebagai vanillin setelah melalui proses spektrofotometri, serta sebagai bubuk vanili dengan proses mikroenkapsulasi dan ekstrak.

4. Biji panili diekstrak dapat menghasilkan bahan pengawet minuman, antikanker, antijamur, dan es krim.

5. Sedangkan akar panili dapat digunakan sebagai antinyamuk melalui proses akstrak.

Manfaat bagian pohon sepertiri daun, batang, buah, biji, dan akar panili dapat diketahui setelah dilakukan analisis terhadap setiap artikel jurnal yang telah dikumpulkan.

Rangkuman pembahasan di atas dapat digambarkan dalam skema sebagai berikut: 


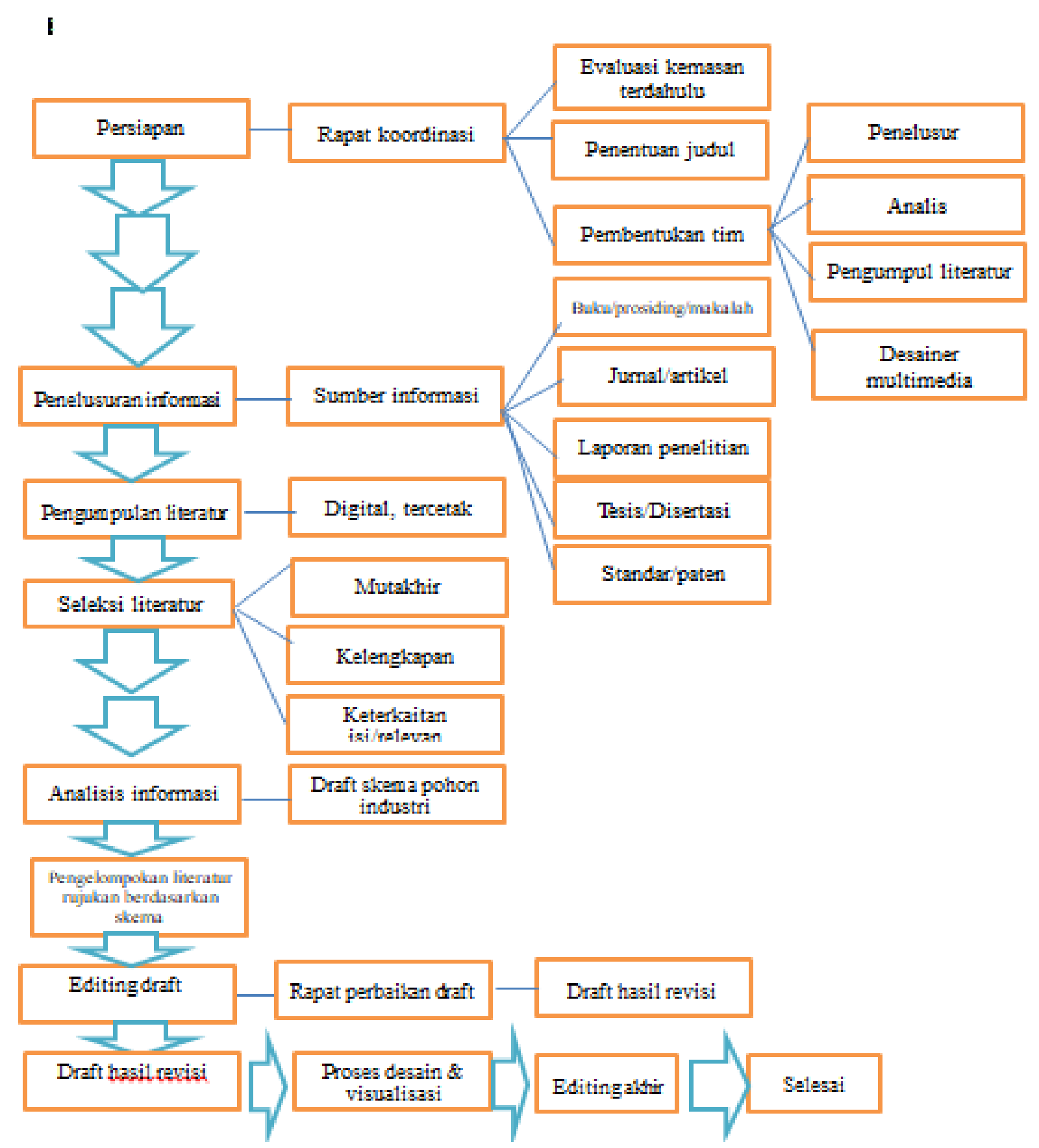

Gambar 3. Skema pembuatan pohon industri

\section{Desain dan visualisasi}

Dari tabel analisis tersebut di atas kemudian tim bagian desain dan visualisasi dengan arahan dari pembuat analisis pohon industri terutama dalam menghubungkan link proses dan hasil dengan artikel yang menjadi rujukan. Untuk memudahkan bagain pembuat desain visualisasi biasanya para analisis sudah me-link-an antara hasil analisis dengan artikel yang mendukungnya. Proses desain dan visualisasi dilakukan dengan maksud supaya lebih interaktif, mudah dicerna, dan tentunya dapat diakses dengan mudah dan dimanfaatkan oleh 
masyarakat luas, karena bisa dipasang di Website yang dimiliki lembaga. Rahma (2020) menyebutkan bahwa pembuatan pohon industri dalam bentuk visualisasi dapat mempermudah penyampaian informasi dalam bentuk spacial maupun non spacial.

Ada tiga menu dalam produk pohon industri interaktif yaitu tampilan utama (cover), menu utama, dan visualisasi hasil analisis. Tampilan utama (cover) berisi tentang deskripsi komoditi dan digunakan untuk memulai membuka, Menu utama menunjukkan bagan atau skema kegunaan dari masing-masing bagian komoditi, sedangkan visualisasi hasil analisis, menunjukkan kegunaan dan cara/proses pembuatan produk yang di-link-kan dengan artikel sebagai rujukannya. Berikut contohnya hasil desain dan visualisasi pohon industri durian.

\subsection{Pohon industri yang telah buat PDDI LIPI}

Pertama kali dibuat pohon industri adalah pada tahun 1999 waktu itu negara kita dalam keadaan krisis moneter. PDDI membuat berbagai jenis kemasan informasi di antaranya adalah pohon industri dan panduan usaha. Pohon industri menginformasikan bagaimana produk luaran yang dihasilkan oleh suatu komoditi sedangkan panduan usaha lebih kepada cara membuat dan analisis biaya dengan pendekatan teknologi tepat guna (sederhana) sebagai contoh: cara membuat nata de coco, gula semut, bubuk cabai, kecap air kelapa dan sebaginya. Di samping mengemas informasi tersebut, dalam rangka partisipasi membantu masyarakat yang terkena dampak krismon PDDI juga menyelenggarakan pelatihan dengan tujuan memberikan pembekalan bagi masyarakat yang berminat mengembangkan usaha setelah terkena PHK.

Mengemas ulang informasi dalam bentuk pohon industri adalah kegiatan menganalis suatu informasi yang disajikan ke dalam bentuk yang tepat dan mudah dipahami oleh masyarakat. Suatu informasi dikatakan bermanfaat apabila informasi tersebut dapat memberi nilai pengetahuan bagi pemakainya. Pohon industri merupakan bentuk kemas ulang informasi yang dapat memberikan informasi kepada masyarakat dalam bentuk yang menarik dan mudah diterima (Alfiana dan CMS, 2020).

Daftar Pohon Industri (Interaktif) yang pernah dibuat oleh PDII LIPI dapat dilihat di tabel sebagai berikut:

Tabel 2. Daftar pohon industri (interaktif)

\begin{tabular}{|c|l|c|l|}
\hline No & \multicolumn{1}{|c|}{ Judul Pohon Industri } & Tahun & \multicolumn{1}{|c|}{ Analis } \\
\hline 1. & Singkong & 1999 & Anonim \\
\hline
\end{tabular}




\begin{tabular}{|c|c|c|c|}
\hline 2. & Kelapa & 1999 & Anonim \\
\hline 3. & Pisang & 2000 & Rahartri \\
\hline 4. & Kedelai & 2000 & Rahartri dan S. Prahastuti \\
\hline 5. & Sapi & 2004 & Sri Lestari \\
\hline 6. & Ikan & 2004 & Rahartri \\
\hline 7. & Kemiri & 2004 & Ambar Yoganingrum \\
\hline 8. & Lamun & 2004 & Sobari \\
\hline 9. & Nanas & 2009 & Ira Maryati dan Rahartri \\
\hline 10. & Pinang & 2009 & Tupan dan Budi Nugroho \\
\hline 11. & Rumput Laut & 2009 & Rahartri \\
\hline 12. & Jarak Pagar & 2009 & Arifah Sismita \\
\hline 13. & Teknologi Nano & 2009 & Yaniasih \\
\hline No & $\begin{array}{c}\text { Judul Pohon Industri } \\
\text { Interaktif }\end{array}$ & Tahun & Analis \\
\hline 1. & Tembakau & 2018 & Tupan \& Rulina \\
\hline 2. & Padi & 2018 & Yaniasih \\
\hline 3. & Kopi & 2018 & Ira Maryati \& M. Djaenudin \\
\hline 4. & Manggis & 2018 & Arifah Sismita \\
\hline 5. & Buah Naga & 2019 & Rahartri \\
\hline 6. & Durian & 2019 & Noorika \& Nurida \\
\hline 7. & Pisang & 2019 & M. Djaenudin \\
\hline 8. & Cabai & 2019 & Tupan \\
\hline
\end{tabular}




\begin{tabular}{|c|l|c|l|}
\hline 9. & Jeruk & 2019 & Ludya A. \& Sutarsyah \\
\hline 10. & Jambu Merah & 2020 & Rulina \& Rahartri \\
\hline 11. & Vanili & 2020 & Tupan \\
\hline
\end{tabular}

\section{Contoh-contoh Pohon Industri}

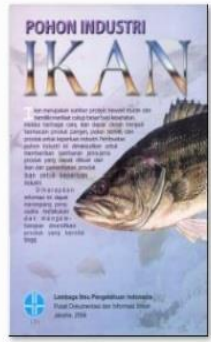

ikan1

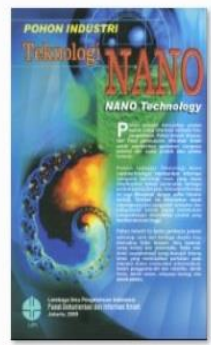

nano1

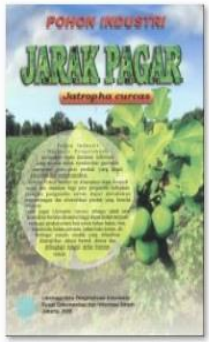

jarak1

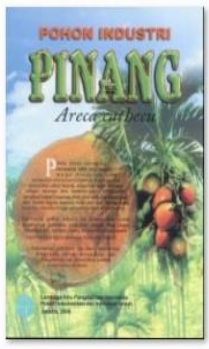

pinang1



kelapa1



rumput1

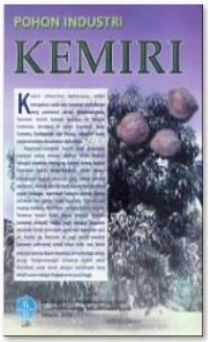

kemiri1

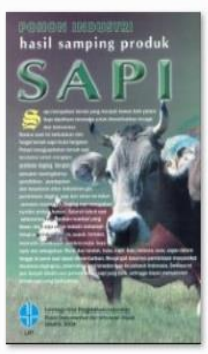

sapi1

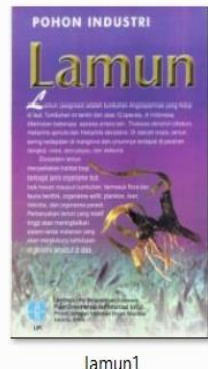

lamuni



singkon1

Gambar 4. Contoh pohon industri

\section{Contoh-contoh Pohon Industri Interaktif:}

\section{Buah Naga}



Tampilan Utama

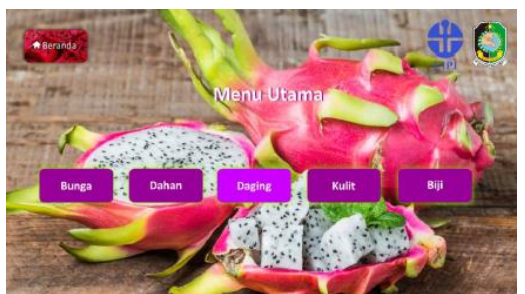

Menu Utama

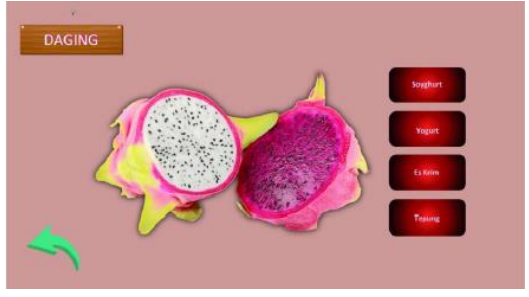

Visualisasi hasil analisis

Gambar 5. Pohon industri interaktif buah naga

\section{Durian}






Tampilan Utama

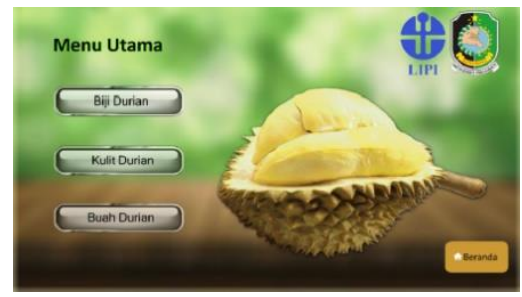

Menu Utama

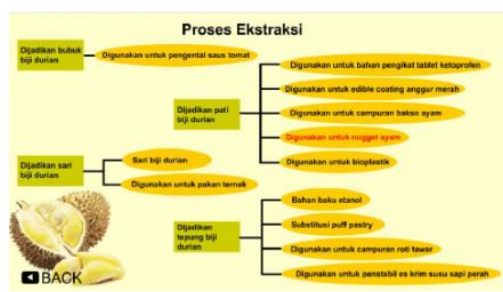

Visualisasi hasil analisis

Gambar 6. Pohon industri interaktif durian

\section{Pisang}

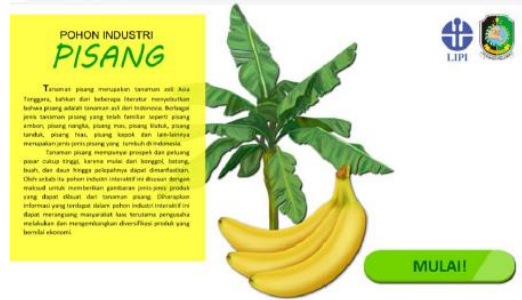

Tampilan Utama

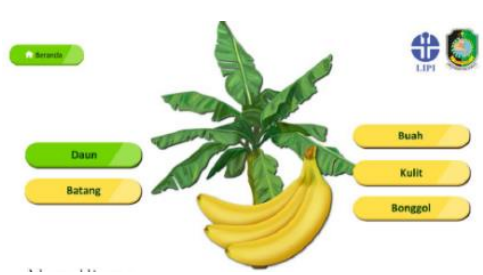

Menu Utama

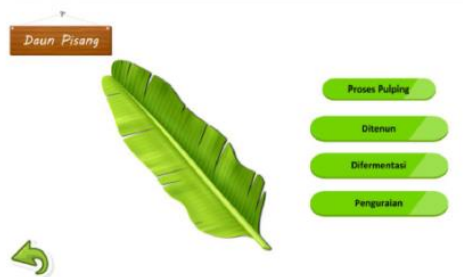

Visualisasi hasil analisis

Gambar 6. Pohon industri interaktif pisang

\section{Durian}



Tampilan utama/cover

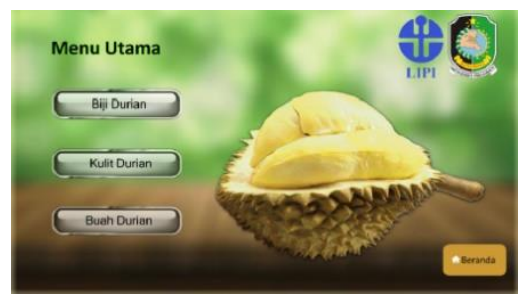

Menu utama

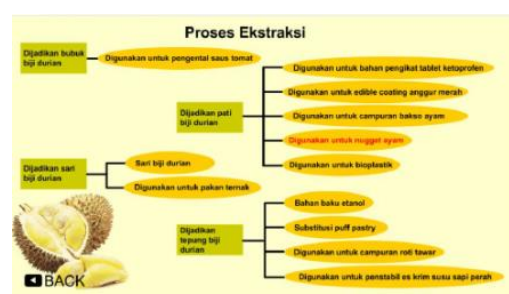

Visualisasi hasil analisis

Gambar 7. Pohon industri interaktif durian

\section{Cabai}

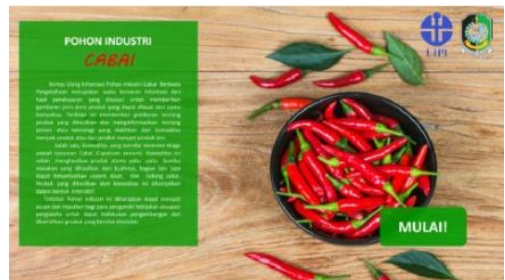

Tampilan Utama

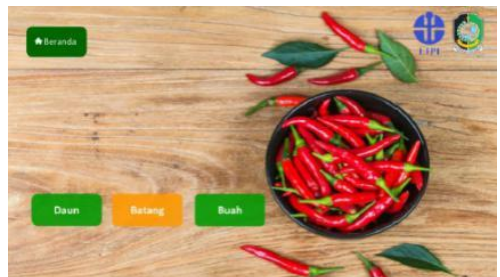

Menu Utama

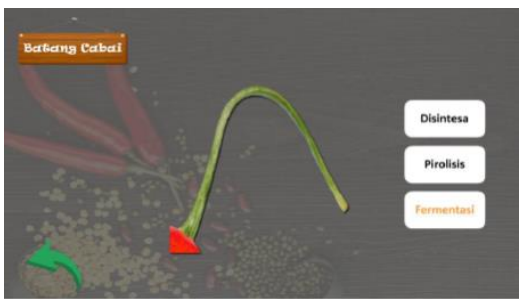

Visualisasi hasil analisis 


\section{Jeruk}

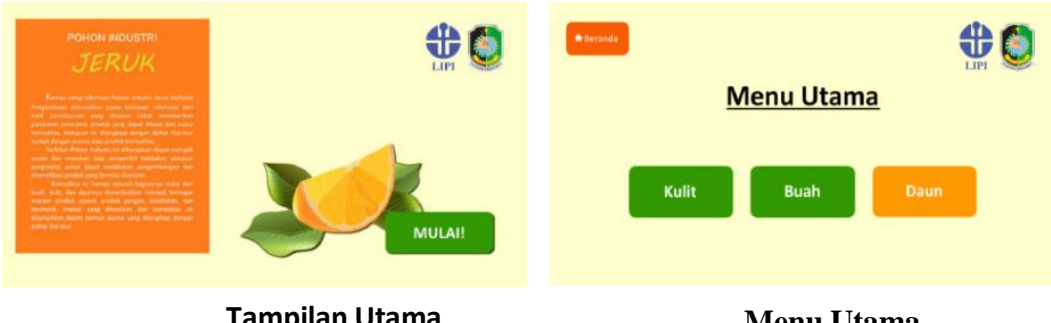

Tampilan Utama

Menu Utama

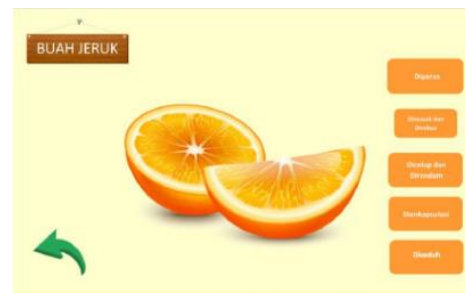

Visualisasi hasil analisis

Gambar 9. Pohon industri interaktif jeruk

\subsection{Pemanfaatan Pohon Industri (Interaktif)}

Dalam rangka pemanfaatan produk pengetahuan yang telah dimiliki PDDI berupa Pohon Industri Interaktif, telah diadakan kerjasama terkait produk pengetahuan yang telah dibuat dan dapat dimanfaatkan oleh banyak masyarakat. Produk pengetahuan yang telah dirangkai, divisualisasikan dan diinformasikan melalui media peta digital. Hal ini dilakukan diharapkan produk pengetahuan berupa pohon industri akan lebih mudah diakses dan dimanfaatkan oleh masyarakat.

Untuk mendayagunakan pemanfaatan pohon industri interaktif pada tahun 2019 PDDI LIPI melakukan kerjasama dengan Pemerintah Daerah Kabupaten Banyuwangi yang memiliki WebGIS. WebGIS adalah aplikasi GIS atau pemetaan digital yang memanfaatkan jaringan internet sebagai media komunikasi yang berfungsi mendistribusikan, mempublikasikan, mengintegrasikan, mengkomunikasikan dan menyediakan informasi (Rahma, 2020). Melihat bahwa pemetaan dapat memberikan dampak yang positif, maka dengan ide yang sama, PDDI ingin membuat peta untuk pemetaan potensi suatu daerah yang dilengkapi dengan informasi mengenai hasil penelitian/teknologi/paten/inovasi yang berkaitan dengan potensi yang dimiliki, yaitu dengan mempertimbangkan kekayaan alam hayati dan potensi wisatanya.

Dengan pemasangan produk pengetahuan (Pohon industri interaktif) ke dalam aplikasi GIS atau BAGOES (sebutan aplikasi di Banyuwangi) yang dimiliki Pemda Banyuwangi maka Pohon Industri Interaktif tersebut siap diakses oleh masyarakat luas agar dapat mengaplikasikan dalam kehidupan sehari-hari. Selain dapat dimanfaatkan oleh masyarakat, produk pengetahuan dalam bentuk pohon industri ini dapat dimanfaatkan juga oleh pemerintah dalam pengambilan kebijakan terutama dalam hal pengembangan sumber daya. Adapun untuk para akademisi pohon industri juga dapat memanfaatkannya sebagai bahan untuk kajian lebih lanjut.

Dalam kegiatan tahun 2020 PDDI LIPI masih melakukan pembuatan produk pengetahuan pohon industri interaktif yang rencananya akan disiapkan dan dimanfaatkan untuk Pemerintah 
Daerah Kabupaten Temanggung sebanyak 5 judul yaitu, tembakau, durian, kopi, vanili, dan jambu biji merah. Pemanfaatan pohon industri ini tidak lepas dari tugas dan fungsi PDDI LIPI sebagai lembaga yang terus berusaha agar keberadaannya dapat dirasakan dan bermanfaat bagi masyarakat luas. Hal ini tertuang dalam penetapan kinerja LIPI yang diamanahi melalui PDDI dengan sasaran program meningkatkan produktivitas dan daya saing sumber daya program dukungan riset dan inovasi LIPI melalui kegiatan inovasi yang siap dimanfaatkan pemerintah/pemerintah daerah/masyarakat sebagai indikatornya pembuatan produk pengetahuan berupa pohon industri interaktif.

Rahma (2020) menyebutkan bahwa pohon industri interaktif memiliki beberapa manfaat antara lain mempermudah pihak eksternal untuk mengetahui produk yang dihasilkan oleh instansi; menyediakan informasi alternatif yang bermanfaat untuk user; memudahkan penyampaian informasi kepada masyarakat mengenai suatu produk tertentu yang lebih menarik; mengetahui manfaat dari suatu produk komoditas tertentu; sebagai media promosi perpustakaan yang interaktif dan menarik; membatu dalam pembuatan materi publikasi dan informasi; kemasan informasi menjadi lebih menarik; dan sebagai sarana diseminasi informasi.

\section{PENUTUP}

\section{Kesimpulan}

Produk pengetahuan berupa pohon industri interatif adalah kemasan informasi yang dibuat sebagai inovasi untuk pustakawan dalam rangka mendukung pengembangan layanan perpustakaan yang berguna bagi masyarakat/pengusaha yang berminat melakukan pengembangan produk bernilai ekonomi. Pohon industri ini mengandung informasi berupa ulasan, skema, dan pemanfaatannya serta referensi (sumber artikel) yang terkait dengan topik tertentu. Disusun berdasarkan fungsi dan manfaat atas suatu komoditas yang bernilai ekonomis dikemas secara interaktif dengan tujuan memberikan gambaran jenis-jenis produk yang dapat dibuat dari suatu komoditas, informasi yang disajikan bertujuan untuk memotivasi pengusaha untuk melakukan inovasi diversifikasi produk yang bernilai ekonomi.

Pohon industri interatif saat ini dibuat dan dimanfaatkan oleh Pemerintah Daerah yang telah bekerja sama dengan PDDI LIPI dengan fokus pada daerah yang mempunyai hasil tanaman perkebunanan atau komoditas lainnya yang menjadi andalan dan memungkinkan diimplementasikan oleh masyarakat/pengusaha.

Pohon industri interatif dapat dipasang di Website yang dimiliki lembaga dengan jaringan internet sebagai media komunikasi yang berfungsi mendistribusikan, mempublikasikan, mengintegrasikan, mengkomunikasikan dan menyediakan informasi bagi masyarakat, agar dapat memicu inovasi-inovasi yang dimiliki sehingga dapat mengembangkan SDM baik masyarakat lokal maupun nasional serta mampu menciptakan masyarakat yang inklusif nan mandiri. Selain itu pohon 
industri interaktif ini dapat dimanfaatkan juga oleh pemerintah dalam pengambilan kebijakan terutama dalam hal pengembangan sumber daya manusianya.

\section{DAFTAR PUSTAKA}

Alfiana, Alwi dan CMS, Samson. (2020). Layanan Kemas Ulang Informasi Berbasis Digital. PUSTABIBLIA: Journal of Library and Information Science, 4(2), 245-264

Agbaji, Y.O. \&Odumu, W.(2017). Information Repackaging: A Panacea for Libraries and Information Resource Centres in Nigeria. International Journal of Business and Management Invention 6(6) : 59-63.

Dongardive, Prakash (2013). Information Repackaging in Library Services. International Journal of Science and Research (IJSR), 2(11), 204-209

Import.io.(2019).What is data visualization and why is it important? https://www.import.io/post/what-is-data-visualization/, diakses 03 Agustus 2020.

Mohamad Djaenudin dan Tupan. 2020. Pengembangan Produk Pengetahuan Sebagai Inovasi Layanan Perpustakaan di Era Industri 4.0. Jurnal IPI (Ikatan Pustakawan Indonesia) Vol. 5 No. 1 (2020): 184-195

Mohamad Djaenudin dan Cahyo Trianggoro. 2019. Inovasi Layanan Perpustakaan Khusus Dalam Ekosistem E-Research dalam mendukung Open Science : Studi Kasus Perpustakaan PDDI LIPI. Makalah yang dipresentasikan dalam Seminar Nasional dan Call for Paper Perpustakaan UIN Jakarta, 28-29 November 2019.

Pebrianti, Yeni . (2015). Kemas Ulang Informasi: Kumpulan Karya Tulis Ilmiah di BPPBAT Bogor. Jurnal Pari, (1) 1, 27-33

Rahma, N. M. (2020). WebGIS sebagai media diseminasi kemas ulang informasi. Berkala Ilmu Perpustakaan dan Informasi, 16 (2), 224-238

Tableau. (2020). Data visualization beginner's guide: a definition, examples, and learnig resources. https://www.tableau.com/learn/articles/data-visualization, diakses 03

Agustus 2020

Tupan dan Nashihuddin, Wahid. (2015). Kemas ulang informasi untuk memenuhi kebutuhan Usaha Kecil dan Menengah : Tinjauan analisis di PDDI LIPI. BACA: Jurnal Dokumentasi dan Informasi, 36 (2), 109-124 